\title{
Animal production and soil characteristics from integrated crop-livestock systems: toward sustainable intensification
}

\author{
Paulo César de Faccio Carvalho, ${ }^{*, 1}$ Caitlin Adair Peterson, ${ }^{\dagger}$ \\ Pedro Arthur de Albuquerque Nunes, * Amanda Posselt Martins, ${ }^{\ddagger}$ William de Souza Filho,* \\ Vanessa Thoma Bertolazi, ${ }^{\ddagger}$ Taíse Robinson Kunrath, * Aníbal de Moraes,, and Ibanor Anghinoni ${ }^{*}$ \\ *Department of Forage Plants and Agrometeorology, Federal University of Rio Grande do Sul, Porto Alegre, \\ RS 91540-000, Brazil; 'Department of Plant Sciences, University of California, Davis, Davis, CA 95616; \\ Department of Soil Science, Federal University of Rio Grande do Sul, Porto Alegre, RS 91540-000, Brazil; \\ "Department of Plant Science and Phytosanitation, Federal University of Paraná, Curitiba, PR 80035-050, Brazil
}

\begin{abstract}
Sustainable intensification of landuse practices has never been more important to ensure food security for a growing world population. When combined under thoughtful management, cover cropping and crop-livestock integration under no-till systems can benefit from unexpected synergies due to their unique features of plant-animal diversification and complex agroecosystem functions. Mimicking the nutrient coupling/ decoupling processes of natural ecosystems by diversifying plant and animal components of no-till integrated crop-livestock operations is an essential feature of the design of agroecological
\end{abstract}

systems that support self-regulating feedbacks and lend resilience while increasing productivity and ecosystem service provision. Focusing on grazing animals as drivers of agroecosystem change, we highlight the benefits of grazed cover crops in rotation with cash crops for primary and secondary production and for soil physical, chemical, and biological parameters. However, careful management of grazing intensity is imperative; overgrazing drives soil deterioration, while light to moderate grazing enhances overall system functioning and allows for the generation of emergent properties.

Key words: cover crops, emergent properties, grazing, integrated crop-livestock systems, soil, sustainable intensification

(C) The Author(s) 2018. Published by Oxford University Press on behalf of the American Society of Animal Science. All rights reserved. For permissions, please e-mail: journals.permissions@oup.com.

J. Anim. Sci. 2018.96:3513-3525 doi: $10.1093 /$ jas/sky085

\section{INTRODUCTION}

Despite modern gains in production efficiency, crop and livestock production are at the center of a number of contemporary environmental issues. Among these are the expansion of agricultural land area, which contributes to the conversion of sensitive and endangered ecosystems (Tilman et al., 2001; Oliveira et al., 2017), greenhouse gas emissions from agriculture that account for $10 \%$ to $29 \%$ of the global total (Vermeulen et al., 2012;

${ }^{1}$ Corresponding author: paulocfe@ufrgs.br

Received January 4, 2018.

Accepted April 20,2018.
FAO, 2016), widespread topsoil degradation (Lal, 2009), and de-coupled nutrient cycles that demand heavy reliance on external inputs (Lemaire et al., 2015) and create nutrient excesses that compromise water resource quality (Verhoeven et al., 2006).

At the same time, productive and reliable agriculture is never more important to ensure food security for a growing world population under unpredictable future climate scenarios. The sustainable intensification of land-use practices is therefore a critical component of agricultural progress in the coming years to meet productivity goals without compromising social and ecological outcomes (Tilman et al., 2011). 
No single practice or management strategy will be enough to achieve these goals (Keating et al., 2014); rather, an assemblage of approaches is called for, calibrated for local contexts and environmental conditions. Here we discuss 2 such approaches, neither of which is new or unprecedented, but which when combined under thoughtful management can benefit from unexpected synergies. One, cover cropping, has been the subject of innumerable reviews and technical experimentation for decades. The other, crop-livestock integration, has become gradually phased out as agricultural systems become more and more specialized (Garrett et al., 2017).

In this review, we examine cover crop grazing as a management strategy for land-use diversification and sustainable intensification of agriculture. Drawing from published examples from around the world, with a special focus on a long-term experiment in southern Brazil, we further outline the potential benefits and drawbacks of grazed cover crops as opposed to cover cropping without grazing by looking at the unique effects of the animal component on agroecosystem processes and functions. Finally, we discuss the importance of adaptive management practices that are sensitive to local environmental and socioeconomic conditions and that emphasize whole-system benefits vs. short-term gain.

\section{COVER CROPS IN CONTEXT}

Cover crops are a single species or mix of species grown during the off season, generally as noncommercial biomass that provides soil cover and reconditioning before the next cropping sequence or perennially in the alleys of vineyards or orchards (Fageria et al., 2005). Grassland leys have been cited as a means to increase carbon sequestration and reduce the amount of gaseous nitrogen lost to the atmosphere in comparison to sole cropping systems through recoupling of carbon-nitrogen cycles (Soussana and Lemaire, 2014). Catch crops, or cover crops used specifically to harvest excess nitrogen from the soil before it can be lost to leaching or runoff, are a strategy to prevent degradation of water quality due to nutrient loading (Kunrath et al., 2015a). Most commonly, leguminous cover crops or green manures have been used to improve soil health and nutrient availability for crops in sequence and to reduce the need to apply mineral fertilizers during the cropping season, among other benefits (Grant et al., 2002).

Other reported positive effects of rotational cover cropping include increase in yield and yield stability with diverse cover crop mixtures (Gaudin et al., 2013), breaking of disease and weed cycles with more diverse cropping sequences that include forages or legumes (Krupinsky et al., 2002), creation of foraging and reproductive habitat for beneficial insects (Smukler et al., 2012), and even increased colonization of annual summer crop roots by arbuscular mycorrhizal fungi (Bowles et al., 2017). However, increasing cover crop biomass and the $\mathrm{C}: \mathrm{N}$ ratio has been shown to negatively affect inorganic $\mathrm{N}$ availability and subsequent crop yield if not managed carefully (Finney et al., 2016). Numerous reviews have already been published on these topics (e.g., Mirsky et al., 2012; Sanderson et al., 2013).

While cover crops are versatile, they add managerial complexity to the system. Challenges that producers must consider when implementing cover crop systems include water use by the cover crop, timing of management activities, and in the case of perennial crops, compliance with food safety regulations and protection from frost damage (Ingels, 1998). Other questions revolve around the most effective way to terminate cover crops before the growing season (e.g., by chemical or mechanical means, and how to ensure that incorporated green manures provide plant available nutrients at critical crop growth stages; Cherr et al., 2006).

\section{COVER CROP GRAZING AND INTEGRATED CROP-LIVESTOCK SYSTEMS}

When cover crops double as high-quality forage, they offer the opportunity to derive additional agricultural product in the form of milk or meat from the same land area supporting crop production during the active season. Cover crop grazing falls under the heading of integrated crop-livestock systems (ICLS), a form of ecological intensification of agriculture that intentionally leverages the functional and biological synergies created by the interaction of plant and animal components. In addition to cover crop grazing, ICLS at the field scale also includes production of dual-purpose crops (Bell et al., 2014), stubble grazing (Sulc and Franzluebbers, 2014), or grazing of understory vegetation in vineyards and orchards (Russelle et al., 2007). These complex agroecosystems rely on spatial, temporal, and(or) biological diversity to support self-regulating feedbacks that can lend resilience to adverse climate conditions while maintaining productivity and ecosystem service provision (Lin, 2011; Khumairoh et al., 2012).

Furthermore, reintegration of livestock into otherwise simplified and specialized agroecosystems is a livelihood strategy that diversifies income and 
reduces risk, although it requires a high degree of managerial adaptability and social and economic capital (Garrett et al., 2017). In the case of cover crop grazing, making multiple uses of the same land area offers additional opportunities for income and increases overall land-use efficiency. In southern Brazil, for example, only 3.5 million hectares are planted annually with winter crops such as wheat or oat. A further 9 million hectares remain either fallow or planted to cover crops that are left ungrazed (Carvalho et al., 2010a). According to some estimates, one young grazing animal on each of these unused hectares of cover crop could yield as much as 700 thousand tonnes of equivalent live-weight - a considerable contribution to land-use efficiency of agricultural areas in the region (Martins et al., 2015).

The most common theme among producers considering implementing cover crop grazing is concern about animal hoof action compacting the soil and negatively affecting the subsequent season's crop yield. Studies give conflicting results on this point, with some showing animal grazing on winter cover crops increasing compaction and decreasing subsequent crop yield (Franzluebbers and Stuedemann, 2008), and others showing an increase in compaction, but no effect (Bell et al., 2011) or even a positive effect on subsequent yield (Tracy and Zhang, 2008; Maughan et al., 2009). When stocking rates are moderate and conditions are dry, others have demonstrated no effect of grazing animals on soil compaction (McKenzie et al., 2017).

On the other hand, when cover crop grazing is considered as part of an inclusive system, conclusions are more consistent. In this case, even when cover crop grazing has a minor negative effect on subsequent crop yield the decrease is more than made up for by the system-wide production response brought about by the addition of livestock products (Oliveira et al., 2013; Franzluebbers and Stuedemann, 2014). These results indicate that multiple factors play a role in crop and system productivity, with the overall outcome of cover crop grazing dependent on the interacting effects of crop rotation, soil type, weather conditions, tillage regime, microeconomic and sociocultural considerations, and perhaps most importantly, good grazing management practices.

\section{GRAZING MANAGEMENT IN ICLS}

Fundamentally, farm-level grazing animal management consists of 2 decisions: determining grazing intensity by establishing the stocking rate in relation to the available forage; and defining the spatiotemporal distribution of animals within the area (Carvalho et al., 2010a). It is well known that stocking method (e.g., rotational or continuous) does not affect animal productivity during the pasture phase (Briske et al., 2008). A study using $10 \mathrm{yr}$ of data from a long-term ICLS with lambs and soybean (Glycine max)/maize (Zea mays) in rotation demonstrated no difference between continuous and rotational stocking method per unit of land; whereas, moderate grazing intensity produced more meat per unit of land than low grazing intensity (Moojen, 2017). However, continuous stocking allows greater individual animal selectivity and intake, resulting in greater individual daily gains, especially in situations of greater forage allowance (Fig. 1; Moojen, 2017).

Stocking method determines the distribution of grazing animals over a specific unit of area, in a specific unit of time, providing more or less managerial control over the frequency, intensity, and uniformity of the defoliation process (Briske et al., 2008). From the spatial perspective, while rotational stocking aims to homogenize grazing distribution, continuous stocking allows little control over animal distribution, allowing them to explore the pasture at will. In any case, grazing intensity is the management tool that truly defines whether an ICLS will be able to successfully reconcile productivity and sustainability (Carvalho et al., 2010a; Soussana and Lemaire, 2014).

The São Miguel das Missões long-term experiment on soybean-beef cattle rotations is emblematic of the management trade-offs among productivity, profitability, and sustainability in a grazed cover crop ICLS. This system in Rio Grande do Sul state of southern Brazil $\left(29^{\circ} 03^{\prime} 10^{\prime \prime} \mathrm{S}\right.$ latitude, $53^{\circ} 50^{\prime} 44^{\prime \prime} \mathrm{W}$ longitude, $465 \mathrm{~m}$ ASL) integrates a black oat (Avena strigosa Schreb.) and Italian ryegrass (Lolium multiflorum Lam.) winter cover crop grazed by beef steers with a summer soybean crop under no-till management. The experiment has accumulated more than $15 \mathrm{yr}$ of data on the effect of different grazing intensities $(10,20,30$, and $40 \mathrm{~cm}$ of sward height, and no grazing) on pasture, animal, crop, and soil metrics (see for example: Oliveira et al., 2013; Assmann et al., 2014; Kunrath et al., 2014; Silva et al., 2014a; Kunrath et al., 2015b).

The low sward height and herbage mass in intensive grazing scenarios affect animal DMI through bite mass limitation (Laca et al., 1992; Gregorini et al., 2011), which consequently affects animal performance. Conversely, light stocking rates favor animal individual performance, but are not financially efficient in converting land to 


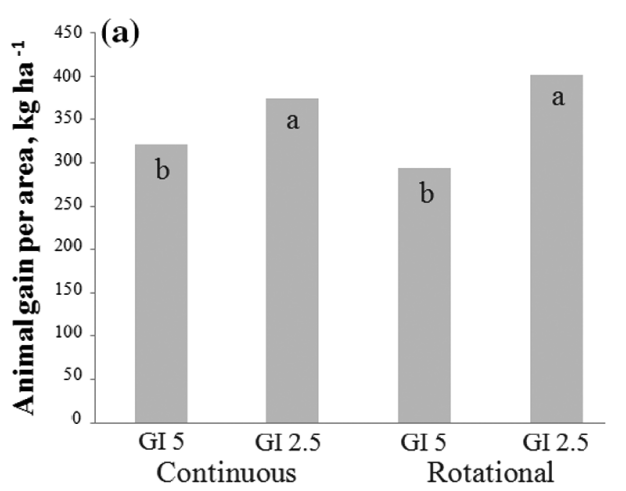

Stocking method

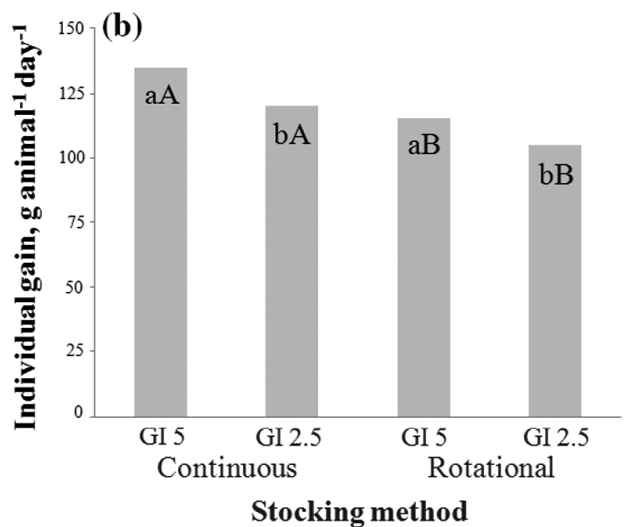

Stocking method

Figure 1. Effect of grazing intensity and stocking method on animal gains (a) per hectare and (b) per head basis in an integrated crop-livestock system. Grazing intensities were expressed as daily herbage allowance of 2.5 and 5 times lambs daily potential DMI. Lower case letters represent grazing intensities. Upper case letters represent stocking methods. Different letters are different according to Tukey test $(P<0.05)$. Data are 10-yr averages from Moojen (2017).

animal product, so that increasing sward heights is only desirable up to a critical point that ensures high returns (Coleman and Solemberger, 2007). Consequently, the optimal grazing intensity would be the one that allows good animal performance both per head and per area basis bounded by uncompromised animal intake (20 to $30 \mathrm{~cm}$ sward height in the São Miguel das Missões example) (Fig. 2; Carvalho et al., 2010a).

In no-till systems, the intensity of forage harvest by grazing ruminants also determines the amount and quality of residual biomass remaining on the soil surface after the stocking period. At São Miguel das Missões, each centimeter of herbage growth represented $\sim 98 \mathrm{~kg} \mathrm{ha}^{-1}$ of DM (Martins et al., 2015), resulting in residues of $1.5,3.4,4.5,5.7$, and $6.5 \mathrm{Mg} \mathrm{ha}^{-1}$ for swards managed at 10,20,30, and $40 \mathrm{~cm}$ height and ungrazed, respectively (Fig. 3). This residual biomass deposition represents a physical barrier to compaction through animal trampling, influencing soil aggregation and water dynamics (Shang et al., 2003) while avoiding runoff and soil losses from erosion.

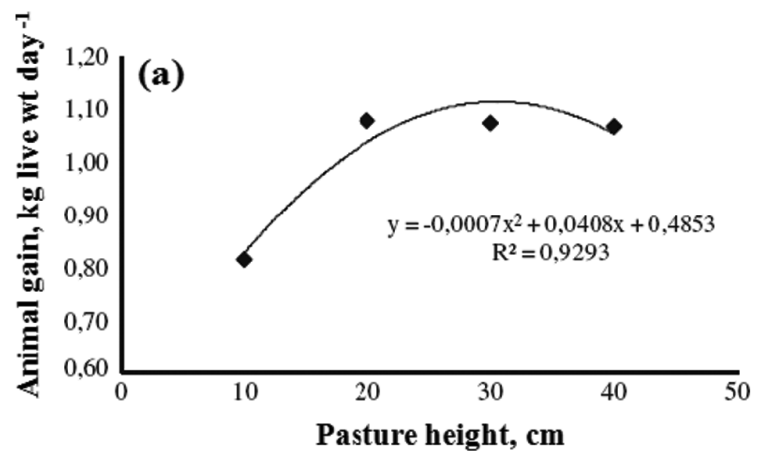

At high grazing intensities, pasture productivity is affected by low herbage mass. The latter is directly related to leaf area index (Lara and Pedreira, 2011), which determines light interception and the biomass accumulation rates. Therefore, biomass accumulation should be greater in taller pastures with greater leaf area index and consequently greater light interception and photoassimilate production. Canopy structure also influences pasture biomass production because young leaves have greater photosynthetic capacity than mature ones $(\mathrm{Xu}$ et al., 2011). At São Miguel das Missões, pastures managed at 20 and $30 \mathrm{~cm}$ sward height had lower lignin contents and faster decomposition rates, evidencing a greater proportion of young leaves in the pastures' composition (Assmann et al., 2015). This result could explain the greater biomass accumulation in moderately to lightly grazed pastures in comparison to ungrazed cover crops (Fig. 3).

Another reason for greater biomass accumulation in grazed cover crops is that tissue removal by animals can facilitate light interception by

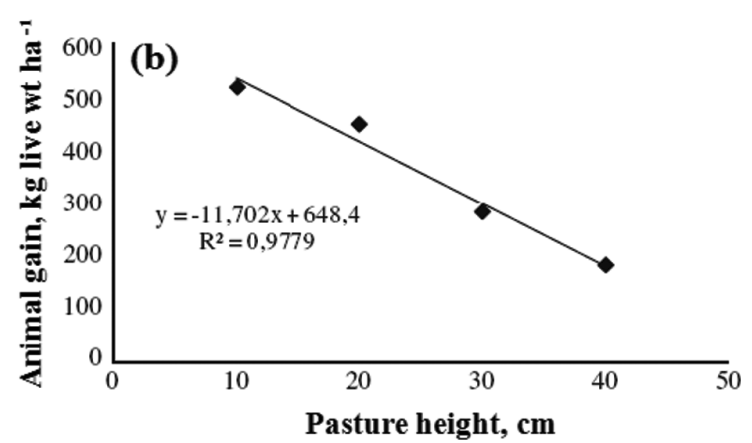

Figure 2. Liveweight gain per animal (a) and per area (b) of steers grazing mixed black oats (Avena strigosa Schreb.) and Italian ryegrass (Lolium multiflorum Lam.) cover crops during the stocking period of an integrated crop-livestock system in southern Brazil. Data are 8-yr averages (Carvalho et al., 2010a). 


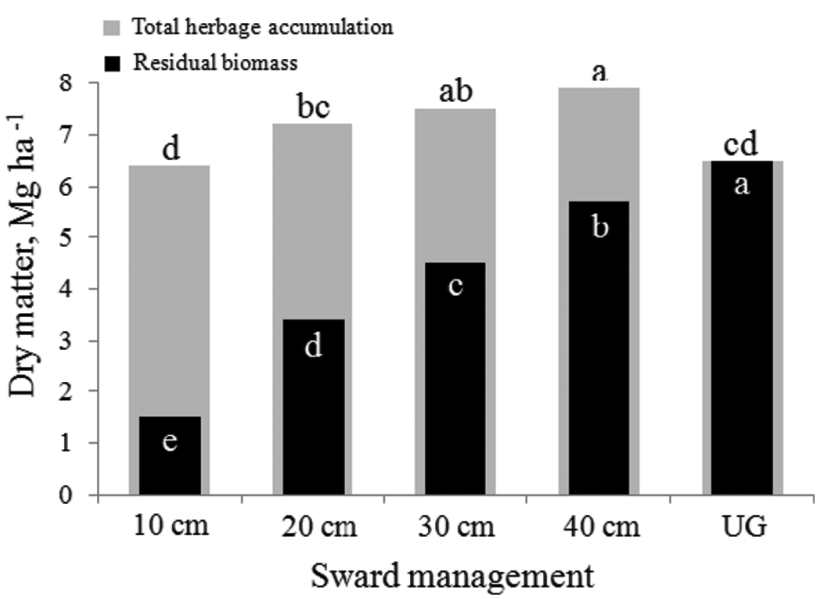

Figure 3. Total herbage $\mathrm{DM}$ accumulation $\left(\mathrm{Mg} \mathrm{ha}^{-1}\right)$ and residual pasture biomass on soil surface $\left(\mathrm{Mg} \mathrm{ha}^{-1}\right)$ at the end of the stocking period in mixed black oat (Avena strigosa Schreb.) and Italian ryegrass (Lolium multiflorum Lam.) grazed cover crops managed under continuous stocking at different sward heights (10 to $40 \mathrm{~cm}$ ) or ungrazed (UG) within a long-term integrated crop-livestock system in southern Brazil. Data are 14-yr averages.

neighboring plants. If remaining leaf tissue is sufficient (i.e., not overgrazed), the result is only a slight reduction in plant-level carbon assimilation and better performance at the canopy level (Lemaire, 2001). Meanwhile, ungrazed shaded grasses tend to invest in structural tissues and increased internode elongation (Ballaré et al., 1991), resulting in early flowering, lodging, and overall shortening of the pasture growth cycle (Rocha et al., 2004).

While plants are couplers of $\mathrm{C}$ and $\mathrm{N}$ through the formation of plant biomass and return of $\mathrm{OM}$ to the soil, grazing animals are de-couplers of $\mathrm{C}$ and $\mathrm{N}$ that consume plant biomass and release methane and $\mathrm{N}$ to the atmosphere via dung/urine patches and eructation of gases produced during enteric fermentation (Soussana and Lemaire, 2014). Grassland soil organic carbon stocks increase with net primary production and $\mathrm{C}$ supply to soil via root and leaf litter deposition, but if the stocking rate increases more rapidly than herbage production (intensive grazing), this imbalance impairs $\mathrm{C}$ sequestration, increases methane emissions per unit of product (due to reduced intake and individual performance) and unit of land (Thornton and Herrero, 2010), and leads to increased risk of $\mathrm{N}$ leaching from dung/urine patches (Soussana and Lemaire, 2014). Trade-offs between production and environmental conservation should therefore be analyzed through the lens of "environmental carrying capacity" (Soussana and Lemaire, 2014), that is, the optimized stocking rate (or grazing intensity) to achieve the balance between coupling and decoupling processes of plant and animal components.

\section{INTEGRATING THE ANIMAL COMPONENT: WHOLE SYSTEM PERFORMANCE, SUSTAINABILITY, AND RESILIENCE}

In the soil-plant-animal-atmosphere continuum that composes ICLS, the soil component is a driver of sustainability and resilience (Anghinoni et al., 2013; Moraes et al., 2014). Besides being the medium through which water and nutrients are absorbed by plants (Lal, 2009), soil also acts as the "memory of the system," centralizing and capturing the modifications imposed by system processes (Anghinoni et al., 2013). The ramifications of this system memory can range from the fostering of emergent properties (i.e., the properties in complex ecosystems that lead to a higher organization state derived from the interaction among system components; Odum, 1953), to impacts on system resilience and economic profitability.

\section{Global Soil Quality Amelioration from ICLS}

Agricultural sustainability revolves around food and fiber production in a fully functional soil environment that is ecologically safe (Vezzani and Mielniczuk, 2009), a goal for which there are several soil-based indicators. Soil microbial attributes are indicators of short-term changes in soil quality (Souza et al., 2014; van Leeuwen et al., 2015) because of microorganisms' role in synthesis and release of extracellular enzymes that are fundamental to plant residue decomposition, and nutrient mineralization (Babujia et al., 2010). Soil OM (total and its fractions) is also a key indicator of soil quality in different soil management regimes (Babujia et al., 2010; Souza et al., 2014).

Several studies at São Miguel das Missões have shown improvement in soil quality indicators when cover crops were grazed rather than ungrazed. Carbon accumulation was shown to be similar between grazed and ungrazed treatments in various studies (e.g., Souza et al., 2009; Assmann et al., 2014; Silva et al., 2014b; Fig. 4). However, intensive grazing was associated with lower carbon stocks when compared to the other grazing intensities as a result of the absence of carbon accumulation in the soil, regardless of the soil layer. This result was due to the lower DM accumulation and poor soil cover in intensively grazed paddocks (see Fig. 3), which promotes higher soil temperatures and accelerates microbial activity and OM decomposition rates (Souza et al., 2010). However, moderate to light grazing intensities resulted in soil $\mathrm{C}$ stocks similar to the ungrazed areas (Fig. 4). 


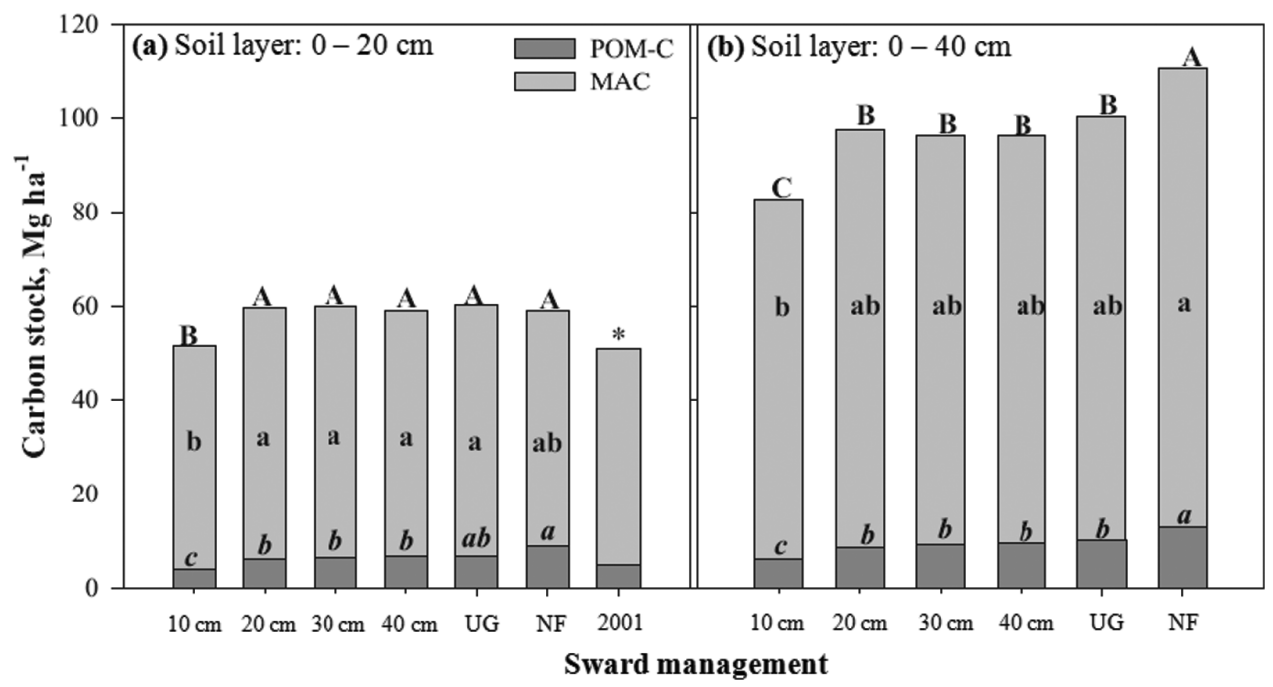

Figure 4. Total carbon, particulate organic matter carbon (POM-C), and mineral associated carbon (MAC) in 0 to $20 \mathrm{~cm}$ (a) and 0 to $40 \mathrm{~cm}$ (B) soil layers in an integrated crop-livestock system managed at different grazed cover crop heights (10 to $40 \mathrm{~cm}$ ) or ungrazed (UG) in southern Brazil. NF $=$ native forest. Different letters are different according to Tukey test $(P<0.05)$. Data are from $2010,9 \mathrm{yr}$ after trial establishment $(*)$ (Assmann et al., 2014).

Considering only the pasture residue, it should be expected to observe lower $\mathrm{C}$ stocks in the grazed areas because the lower the sward management height, the smaller the amount of residue, the smaller the $\mathrm{C}$ accumulation. However, it is common for $\mathrm{C}$ stocks to follow a trend (Fig. 4) very similar to that observed for total herbage accumulation (Fig. 3). Grazing animals act as catalysts to the soil-plant-atmosphere continuum, modifying the rates and flows of processes and recycling organic material (Anghinoni et al., 2013). In the case of C, new entry routes are added with cover crop grazing, such as urine and manure patches (Assmann et al., 2015). In addition, the grazing of cover crops stimulates root production (Souza et al., 2009), whose importance for $\mathrm{C}$ sequestration and accumulation is widely recognized (Kell, 2012). Thus, a redistribution of the accumulated $\mathrm{C}$ occurs; storage occurs mostly on the soil surface in ungrazed areas (Assmann et al., 2014), and in deeper layers in ICLS, making the latter less susceptible to oxidation losses (i.e., OM decomposition). In the long term, this redistribution and physical protection leads to greater $\mathrm{C}$ accumulation in the ICLS (Carvalho et al., 2010b; Salton et al., 2014), especially when deeper soil layers are analyzed.

Greater $\mathrm{C}$ accumulation and especially the new routes and fluxes of $\mathrm{C}$ into the soil caused by cover crop grazing directly impact the activity of soil microbiota, which use $\mathrm{C}$ as a primary source of energy (Legay et al., 2014). Several studies have demonstrated the benefit of cover crop grazing and adoption of ICLS for the abundance and diversity of soil fauna (Souza et al., 2010; Moraes et al. 2014;
Silva et al., 2015) and for the functionality of these populations with regard to nutrient cycling and OM accumulation and stabilization (Chávez et al., 2011; Davinic et al., 2013).

Furthermore, the altered C dynamics in ICLS suggest opportunities for mitigation of greenhouse gas emissions from animal production. Livestock production systems are implicated as major contributors to anthropogenic greenhouse gas emissions, although estimates as to their true contribution to greenhouse gas emissions from agriculture vary widely (Pitesky et al., 2009; Gerber et al., 2013; Aiking, 2014). However, several studies in Brazil have shown that ICLS, besides intensifying land use and diversifying production, have the potential to contribute to the reduction of greenhouse gas emissions (mainly $\mathrm{CO}_{2}, \mathrm{CH}_{4}$, and $\mathrm{N}_{2} \mathrm{O}$ ) per unit of agricultural product (Savian et al., 2014; Figueredo et al., 2017; Sá et al., 2017). Specifically, methane emission intensity ( $\mathrm{g} \mathrm{CH}_{4}$ per unit of product) is greater in extensive pastoral systems than in intensive systems due to the former's low productivity per unit area (Oenema et al., 2014). The production intensification of ICLS in addition to their capacity to store $\mathrm{C}$ in deeper soil layers has potential as a strategy to mitigate $\mathrm{CH}_{4}$ emissions while increasing animal production (Knapp et al., 2014).

\section{Toward the Detection of Emergent Properties from ICLS}

The integration of crop and animal components in agricultural systems confers a new level of complexity to no-till and conservation-tillage 
systems. Animals are dynamic agents that continuously introduce variability through grazing, trampling, and manure distribution. The greater the complexity and diversification of these systems, the greater the potential synergisms among animal, plant, and soil components, ultimately approaching the functionality of natural ecosystems in which the outcome of these interactions is greater than the sum of the individual contributions of each compartment (Kirschenmann, 2007). These emergent properties arise when ecosystems reach such a level of organization that their combined components produce responses that were not previously expressed (Manson, 2001).

This behavior is clear when comparing the effect of surface lime application between grazed cover crops in ICLS and cover crops only in the São Miguel das Missões experiment. High concentrations of toxic aluminum restrict soybean yield in no-till systems. However, 9 yr after the first $\mathrm{pH}$ correction, soybean yields were not affected by high $\mathrm{Al}^{+3}$ levels (Martins et al., 2014a). Soil re-acidification was evaluated before lime reapplication, verifying that regardless of grazing intensity acidification was lower in the grazed areas, with greater base saturation and lower $\mathrm{Al}^{+3}$ saturation in the whole soil profile compared to the ungrazed areas (Fig. 5; Martins et al., 2014b). The ICLS also showed better performance with respect to soil acidity correction, reacting at deeper soil layers under moderate grazing when compared to ungrazed areas ( 40 vs. $17.5 \mathrm{~cm}$ depth, respectively) $30 \mathrm{mo}$ after lime reapplication. The authors attributed these phenomena to greater root production and the presence of dung beetles, both of which increase soil bioporosity and thus promote lime transportation to deeper horizons (Nichols et al., 2008).

As for soil mineralogy, x-ray analysis has revealed greater proportions of 2:1 hydroxy-interlayered minerals (HIM) in grazed compared to ungrazed areas in the São Miguel das Missões experiment $12 \mathrm{yr}$ after its establishment (Bertolazi et al., 2017). Two different types of HIM were found in intensive and moderately grazed areas: the first presented aluminization of the interlayer, and the second presented K-saturated interlayers.
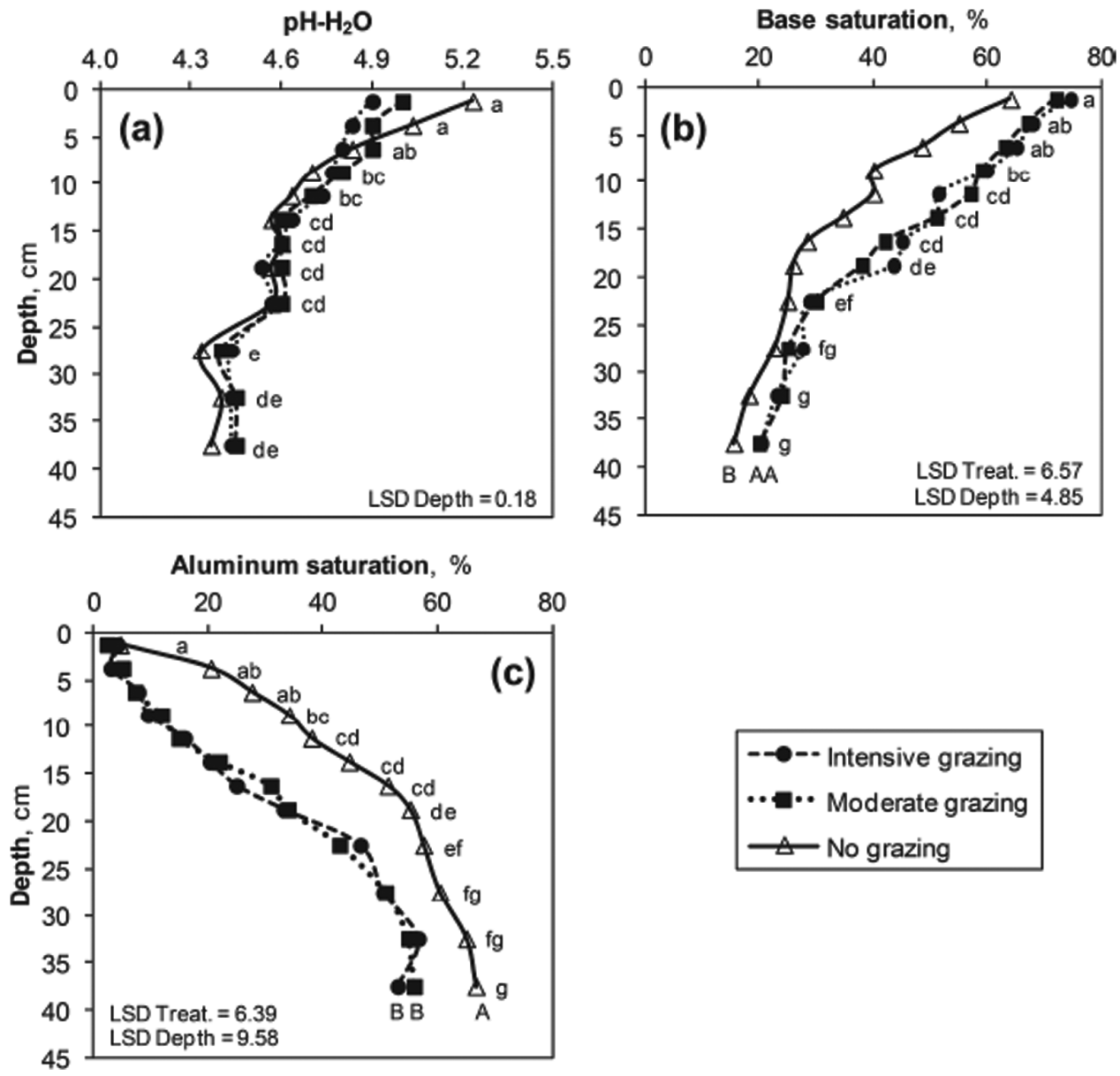

Figure 5. Acidity attributes in soil profile after $9 \mathrm{yr}$ of no-till soybean-beef cattle system with different grazing intensities or ungrazed cover crop. Uppercase letters refer to depths; lowercase letters refer to depths; different letters are different according to Tukey test $(P<0.05)($ Martins et al., 2014b). 
The greater aluminization of the 2:1 interlayers observed under intensive and moderate grazing may have resulted from aluminum being drained by the soil solid phase, making it less available and less toxic to plants; a result that seems to explain the acidity dynamics and the absence of response of soybean yield to $\mathrm{Al}^{+3}$ saturation and liming reported by Martins et al. (2014a, 2014b).

The occurrence of HIM with $\mathrm{K}$ saturation of the interlayer may be associated with the increased nutrient cycling proportioned by bovine manure; the retention of this element within the soil clay mineral fraction may reduce leaching losses and act as a long-term source of $\mathrm{K}$ in the ICLS soils (Bertolazi et al., 2017). Because clay minerals are derived from the weathering of native rock, it seems logical that external influences would not change soil mineralogy in short periods of time. However, these results demonstrate significant, short-term alterations in soil mineralogy, reinforcing the necessity to consider the emergence of new properties from long-term ICLS under no-till management.

\section{Animal Contributions to ICLS Resilience}

Concerns about ICLS performance revolve around cash crop yield reductions after grazing periods due to hoof compacting action or by the consumption of residues that would otherwise serve as soil cover to satisfy no-till principles (Moraes et al., 2014). The impacts of hoof action are highly dependent on soil texture and moisture content. In cold climate ICLS, for example, animals grazing in fall/winter when the ground is still frozen have no impact on surface soil compaction; animals grazing in the spring increase compaction, but not beyond the $2 \mathrm{MPa}$ threshold cone index value where plant performance would be affected (Rakkar et al., 2017). Similarly, grazing can negatively impact subsequent crop yield if it coincides with an abnormally wet season, in which case soil structure can be significantly damaged by trampling (Schomberg et al., 2014). In general, hoof impacts are limited to the soil surface, easily reversible, and unlikely to occur when management actions are conservative and timely (Bell et al., 2011).

In southern Brazilian ICLS, crops following grazed cover crops tend to yield more than ungrazed control areas (Fig. 6; Carvalho et al., 2018). When cover crops are grazed, subsequent crop yields increase by $3.4 \%, 4.7 \%, 10.4 \%$, and $10.8 \%$ for soybean, bean (Phaseolus vulgaris), irrigated rice (Oryze sativa), and maize, respectively. This result contradicts the prevailing paradigm and shows that concerns about detrimental effects of grazing animals on system function do not hold when moderate grazing intensities and conservation agricultural practices are respected (Carvalho et al., 2018).

Furthermore, grain and cattle markets often exhibit complementary trends, and the greater level of diversification in ICLS makes them less sensitive to market fluctuations than single-commodity operations (Ryschawy et al., 2012). That is, fluctuations in annual returns from livestock vs. cash crop commodities are typically uncorrelated, which means that one enterprise can buffer the other from climate and price variability even when operated separately in space (Bell and Moore, 2012).

Animal contributions to resilience are most evident over the long term, especially under unpredictable rain fed conditions, as crop production varies much more than animal production at this time scale. At São Miguel das Missões, pure soybean system produced, on average, $2.8 \mathrm{Mg} \mathrm{ha}^{-1}$ of grains, while the grazed system produced the equivalent of 4.5 $\mathrm{Mg} \mathrm{ha}^{-1}$ (Fig. 7).

In addition to the greater profitability achieved by the integrated system $(+60 \%)$, the additional yield in the form of livestock production in years of crop failure plays a crucial role in system resilience. In this example, the pasture component (i.e., grazing animals) buffers the agronomic component and stabilizes farm income. Similar outcomes have been observed for commercial-scale ICLS in other

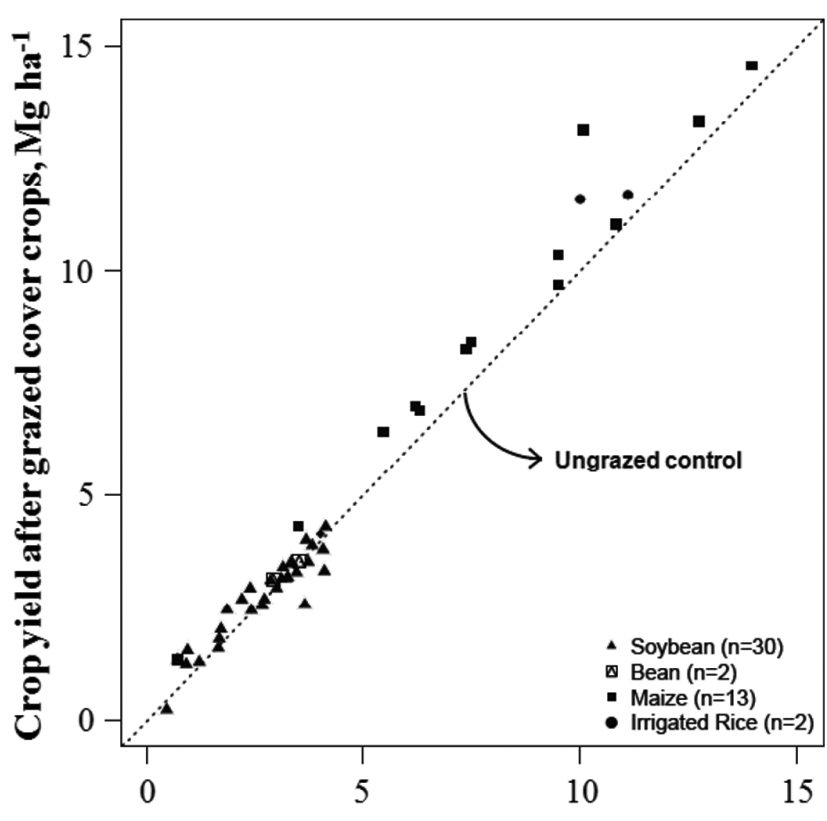

Crop yield after ungrazed cover crops, $\mathrm{Mg} \mathrm{ha}^{-1}$

Figure 6. Crop yield after grazed compared to ungrazed cover crops in Brazilian subtropical integrated crop-livestock systems (adapted from Carvalho et al., 2018). 


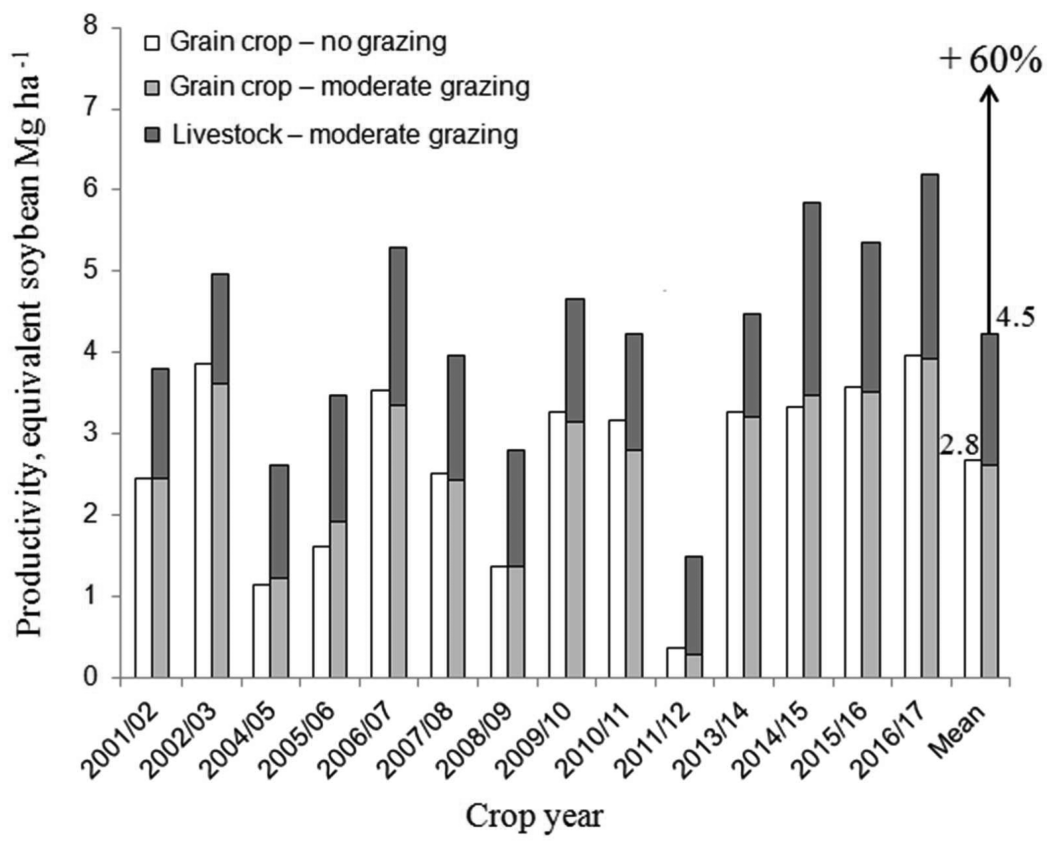

Figure 7. Soybean yield after grazed (light gray bars) or ungrazed (white bars) cover crops. Dark gray bars are steer liveweight gain per area $\left(\mathrm{kg} \mathrm{ha}^{-1}\right)$ on mixed black oat (Avena strigosa Schreb.) and Italian ryegrass (Lolium multiflorum Lam.) grazed cover crops managed with moderate grazing intensity $\left(20 \mathrm{~cm}\right.$ sward height). Liveweight gains were transformed into equivalent soybean productivity $\left(\mathrm{Mg} \mathrm{ha}^{-1}\right)$ by relative soybean and beef cattle market prices from each year (Martins et al., 2015).

regions of the world (e.g., China; Komarek et al., 2015, and Australia; Bell et al., 2014).

\section{SUMMARY AND CONCLUSIONS}

The integration of animals to graze cover crops in rotation with cash crops under no-till management lends a level of complexity in systems functioning rarely observed in modern food production systems. In such systems, emergent properties arise from complex synergies among soil, plants, and animals, where the soil compartment is a reservoir of indicators of higher level ecosystem functioning. Functional diversity is at the core of such phenomena, but the grazing process is the driver of agroecosystem change.

In the examples we cite, the effect of grazing is disentangled from the overall pasture effect usually reported in the literature through the comparison of ungrazed cover crops to grazed cover crops of the same species composition. Thus, the unique effects of the grazing process; namely decoupling (defoliation and defecation) and trampling in enhancing soil quality and provoking unexpected results become clear, as exemplified by $\mathrm{Al}^{+3}$ dynamics and soil mineralogy, among others.

In ICLS, grazing intensity is the management tool that truly drives system functioning toward positive or negative looping feedback. Moderate grazing intensity is essential to promote positive feedbacks that reconcile productivity and sustainability, with implications for greater system resilience and economic profitability.

\section{ACKNOWLEDGMENTS}

Based on a presentation at the Forages and Pastures Symposium: Cover Crops in Livestock Production: Whole-system Approach entitled "Animal production and soil characteristics from integrated crop-livestock systems: Toward sustainable intensification" held at the 2017 ASAS-CSAS Annual Meeting, July 11, 2017, Baltimore, MD. This research was supported by CNPq, CAPES, Fundação Agrisus, and IAEA. Acknowledgements to the Garcia de Garcia family for their fundamental contribution to the São Miguel das Missões long-term experiment.

\section{LITERATURE CITED}

Aiking, H. 2014. Protein production: planet, profit, plus people? Am. J. Clin. Nutr. 100(suppl):483-489. doi:10.3945/ ajcn.113.071209.1

Anghinoni, I., P. C. F. Carvalho, and S. E. V. G. de A. Costa. 2013. Abordagem sistêmica do solo em Sistemas Integrados de Produção Agrícola e Pecuária no subtrópico brasileiro. Tópicos em Ciência do Solo 8:325-380.

Assmann, J. M., I. Anghinoni, A. P. Martins, S. E. V. G. A. Costa, D. Cecagno, F. S. Carlos, and P. C. F. Carvalho. 2014. Soil carbon and nitrogen stocks and fractions in a long-term integrated crop-livestock system under no-tillage in southern Brazil. Agric. Ecosyst. Environ. 190:52-59. doi:10.1016/j.agee.2013.12.003 
Assmann, J. M., I. Anghinoni, A. P. Martins, S. E. V. G. A. Costa, T. R. Kunrath, C. Bayer, P. C. F. Carvalho, and A. J. Franzluebbers. 2015. Carbon and nitrogen cycling in an integrated soybean-beef cattle production system under different grazing intensities. Pesqui. Agropecu. Bras. 50:967-978. doi:10.1590/S0100-204X2015001000013

Babujia, L. C., M. Hungria, J. C. Franchini, and P. C. Brookes. 2010. Microbial biomass and activity at various soil depths in a Brazilian oxisol after two decades of no-tillage and conventional tillage. Soil Biol. Biochem. 42:2174-2181. doi:10.1016/j.soilbio.2010.08.013

Ballaré, C. L., A. L. Scopel, and R. A. Sánchez. 1991. Photocontrol of stem elongation in plant neighbourhoods: effects of photon fluence rate under natural conditions of radiation. Plant Cell Environ. 14:57-65. doi:10.1111/j.1365-3040.1991.tb01371.x

Bell, L. W., J. A. Kirkegaard, A. Swan, J. R. Hunt, N. I. Huth, and N. A. Fettell. 2011. Impacts of soil damage by grazing livestock on crop productivity. Soil Tillage Res. 113:19-29. doi:10.1016/j.still.2011.02.003

Bell, L. W., and A. D. Moore. 2012. Livestock systems in Australian agriculture: trends, drivers and implications. Agric. Syst. 111:1-12.

Bell, L. W., A. D. Moore, and J. A. Kirkegaard. 2014. Evolution in crop-livestock integration systems that improve farm productivity and environmental performance in Australia. Eur. J. Agron. 57:10-20. doi:10.1016/j.eja.2013.04.007

Bertolazi, V. T., A. V. Inda, L. Caner, A. P. Martins, M. A. B. Vaz, M. Bonnet, I. Anghinoni, and P. C. F. Carvalho. 2017. Impact of an integrated no-till soybean-beef cattle production system on Oxisol mineralogy in southern Brazil. Appl. Clay Sci. 149:67-74. doi:10.1016/j.clay.2017.08.028

Bowles, T. M., L. E. Jackson, M. Loeher, and T. R. Cavagnaro. 2017. Ecological intensification and arbuscular mycorrhizas: a meta-analysis of tillage and cover crop effects. J. Appl. Ecol. 54:1785-1793. doi:10.1111/1365-2664.12815

Briske, D. D., J. D. Derner, J. R. Brown, S. D. Fuhlendorf, W. R. Teague, K. M. Havstad, R. L. Gillen, A. J. Ash, and W. D. Willms. 2008. Rotational grazing on rangelands: reconciliation of perception and experimental evidence. Rangel. Ecol. Manag. 61:3-17. doi:10.2111/06-159R.1

Carvalho, P. C. F., I. Anghinoni, A. Moraes, E. D. Souza, R. M. Sulc, C. R. Lang, J. P. C. Flores, M. L. T. Lopes, J. L. S. Silva, O. Conte, et al. 2010a. Managing grazing animals to achieve nutrient cycling and soil improvement in no-till integrated systems. Nutr. Cycl. Agroecosystems 88:259-273. doi:10.1007/s10705-010-9360-x

Carvalho, P. C. F., R. S. Barro, A. B. Neto, P. A. A. Nunes, A. Moraes, I. Anghinoni, C. Bredemeier, C. Bayer, A. P. Martins, T. R. Kunrath, et al. 2018. Integrating the pastoral component in agricultural systems. Rev. Bras. Zootec. (in press).

Carvalho, J. L. N., G. S. Raucci, C. E. P. Cerri, M. Bernoux, B. J. Feigl, F. J. Wruck, and C. C. Cerri. 2010b. Impact of pasture, agriculture and crop-livestock systems on soil C stocks in Brazil. Soil Tillage Res. 110:175-186. doi:10.1016/j.still.2010.07.011

Chávez, L. F., L. F. Escobar, I. Anghinoni, P. C. F. Carvalho, and E. J. Meurer. 2011. Metabolic diversity and microbial activity in the soil in an integrated crop-livestock system under grazing intensities. Pesqui. Agropecu. Bras. 46:1254-1261. doi:10.1590/ S0100-204X2011001000020
Cherr, C. M., J. M. S. Scholberg, and R. McSorley. 2006. Green manure approaches to crop production: a synthesis. Agron. J. 98:302-319. doi:10.2134/agronj2005.0035

Coleman, S. W., and L. E. Sollenberger. 2007. Plant-herbivore interactions. In: R. F. Barnes et al., editors, Forages - the science of grassland agriculture. Blackwell Publishing, Ames, IA. p. 123-136.

Davinic, M., J. Moore-Kucera, V. Acosta-Martínez, J. Zak, and V. Allen. 2013. Soil fungal distribution and functionality as affected by grazing and vegetation components of integrated crop-livestock agroecosystems. Appl. Soil Ecol. 66:61-70. doi:10.1016/j.apsoil.2013.01.013

Fageria, N. K., V. C. Baligar, and B. A. Bailey. 2005. Role of cover crops in improving soil and row crop productivity. Commun. Soil Sci. Plant Anal. 36:2733-2757. doi:10.1080/00103620500303939

FAO. 2016. FAOSTAT agri-environmental indicators, emissions by sector. http://faostat.fao.org/default.aspx (accessed December 22, 2017).

Figueiredo, E. B., S. Jayasundara, R. O. Bordonal, T. T. Berchielli, R. A. Reis, C. Wagner-Riddle, and N. La Scala Jr. 2017. Greenhouse gas balance and carbon footprint of beef cattle in three contrasting pasture-management systems in Brazil. J. Clean. Prod. 142:420-431. doi:10.1016/j.jclepro.2016.03.132

Finney, D. M., White, C. M., and J. P. Kaye. 2016. Biomass production and carbon/nitrogen ratio influence ecosystem services from cover crop mixtures. Agron. J. 108:39-52. doi:10.2134/agronj15.0182

Franzluebbers, A. J., and J. A. Stuedemann. 2008. Soil physical responses to cattle grazing cover crops under conventional and no tillage in the Southern Piedmont USA. Soil Tillage Res. 100:141-153 . doi:10.1016/j.still.2008.05.011

Franzluebbers, A. J., and J. A. Stuedemann. 2014. Crop and cattle production responses to tillage and cover crop management in an integrated crop-livestock system in the southeastern USA. Eur. J. Agron. 57:62-70. doi:10.1016/j. eja.2013.05.009

Garrett, R., M. T. Niles, J. D. B. Gil, A. Gaudin, R. ChaplinKramer, A. Assmann, T. S. Assmann, K. Brewer, P. C. F. Carvalho, O. Cortner, et al. 2017. Social and ecological analysis of integrated crop livestock systems: current knowledge and remaining uncertainty. Agric. Syst. 155:136-146. doi:10.1016/j.agsy.2017.05.003

Gaudin, A., S. Westra, C. Loucks, K. Janovicek, R. Martin, and W. Deen. 2013. Improving resilience of Northern field crop systems using inter-seeded red clover: a review. Agronomy 3:148-180. doi:10.3390/ agronomy 3010148

Gerber, P. J., H. Steinfeld, B. Henderson, A. Mottet, C. Opio, J. Dijkman, A. Falcucci, and G. Tempio. 2013. Tackling climate change through livestock: a global assessment of emissions and mitigation opportunities. Food and Agriculture Organization, Rome.

Grant, C. A., G. A. Peterson, and C. A. Campbell. 2002. Nutrient considerations for diversified cropping systems in the northern Great Plains. Agron. J. 94:186-198. doi:10.2134/agronj2002.0186

Gregorini, P., S. A. Gunter, M. T. Bowman, J. D. Caldwell, C. A. Masino, W. K. Coblentz, and P. A. Beck. 2011. Effect of herbage depletion on short-term foraging dynamics and diet quality of steers grazing wheat pastures. J. Anim. Sci. 89:3824-3830. doi:10.2527/jas.2010-3725 
Ingels, C. A. 1998. Cover cropping in vineyards: a grower's handbook. University of California, Division of Agriculture and Natural Resources, Berkeley, CA.

Keating, B. A., M. Herrero, P. S. Carberry, J. Gardner, and M. B. Cole. 2014. Food wedges: framing the global food demand and supply challenge towards 2050. Glob. Food Sec. 3:125-132. doi:10.1016/j.gfs.2014.08.004

Kell, D. B. 2012. Large-scale sequestration of atmospheric carbon via plant roots in natural and agricultural ecosystems: why and how. Philos. Trans. R. Soc. Lond. B. Biol. Sci. 367:1589-1597. doi:10.1098/rstb.2011.0244

Khumairoh, U., J. C. Groot, and E. A. Lantinga. 2012. Complex agro-ecosystems for food security in a changing climate. Ecol. Evol. 2:1696-1704. doi:10.1002/ece3.27

Kirschenmann, F. L. 2007. Potential for a new generation of biodiversity in agroecosystems. Leopold Center Conference Papers, Salt Lake City, UT.

Knapp, J. R., G. L. Laur, P. A. Vadas, W. P. Weiss, and J. M. Tricarico. 2014. Invited review: enteric methane in dairy cattle production: quantifying the opportunities and impact of reducing emissions. J. Dairy Sci. 97:3231-3261. doi:10.3168/jds.2013-7234

Komarek, A. M., L. W. Bell, J. P. M. Whish, M. J. Robertson, and W. D. Bellotti. 2015. Whole-farm economic, risk and resource-use trade-offs associated with integrating forages into crop-livestock systems in western China. Agric. Syst. 133:63-72. doi:10.1016/j.agsy.2014.10.008

Krupinsky, J. M., K. L. Bailey, M. P. McMullen, B. D. Gossen, and T. K. Turkington. 2002. Managing plant disease risk in diversified cropping systems. Agron. J. 94:198-209. doi:10.2134/AGRONJ2002.1980

Kunrath, T. R., C. Berranger, X. Charrier, F. Gastal, P. C. F. Carvalho, G. Lemaire, J.-C. Emile, and J.-L. Durand. 2015a. How much do sod-based rotations reduce nitrate leaching in a cereal cropping system? Agric. Water Manag. 150:46-56. doi:10.1016/j.agwat.2014.11.015

Kunrath, T. R., M. Cadenazzi, D. M. Brambilla, I. Anghinoni, A. Moraes, R. S. Barro, and P. C. F. Carvalho. 2014. Management targets for continuously stocked mixed oat $\mathrm{x}$ annual ryegrass pasture in a no-till integrated crop-livestock system. Eur. J. Agron. 57:71-76. doi:10.1016/j. eja.2013.09.013

Kunrath, T. R., P. C. F. Carvalho, M. Cadenazzi, C. Bredemeier, and I. Anghinoni. 2015b. Grazing management in an integrated crop-livestock system: soybean development and grain yield. Rev. Ciência Agronômica 46:645-653. doi:10.5935/1806-6690.20150049

Laca, E. A., E. D. Ungar, N. Seligman, and M. W. Demment. 1992. Effects of sward height and bulk density on bite dimensions of cattle grazing homogeneous swards. Grass Forage Sci. 47:91-102. doi:10.1111/j.1365-2494.1992.tb02251.x

Lal, R. 2009. Soils and food sufficiency. A review. Agron. Sustain. Dev. 29:113-133. doi:10.1051/agro:2008044

Lara, M. A. S., and C. G. S. Pedreira. 2011. Structural and morphogenetic responses of swards of Brachiaria species to defoliation intensity. Pesqui. Agropecu. Bras. 46:760 767. doi:10.1590/S0100-204X2011000700012

van Leeuwen, J. P., T. Lehtinen, G. J. Lair, J. Bloem, L. Hemerik, K. V. Ragnarsdóttir, G. Gísladóttir, J. S. Newton, and P. C. de Ruiter. 2015. An ecosystem approach to assess soil quality in organically and conventionally managed farms in Iceland and Austria. Soil 1:83-101. doi:10.5194/ soil-1-83-2015
Legay, N., C. Baxendale, K. Grigulis, U. Krainer, E. Kastl, M. Schloter, R. D. Bardgett, C. Arnoldi, M. Bahn, M. Dumont, et al. 2014. Contribution of above- and below-ground plant traits to the structure and function of grassland soil microbial communities. Ann. Bot. 114:1011-1021. doi:10.1093/aob/mcu169

Lemaire, G. 2001. Ecophysiology of grasslands: dynamic aspects of forage plant populations in grazed swards. In: International Grassland Congress, São Pedro. Vol. 19. p. 29-37.

Lemaire, G., F. Gastal, A. Franzluebbers, and A. Chabbi. 2015. Grassland-cropping rotations: an avenue for agricultural diversification to reconcile high production with environmental quality. Environ. Manage. 56:1065-1077. doi:10.1007/s00267-015-0561-6

Lin, B. B. 2011. Resilience in agriculture through crop diversification: adaptive management for environmental change. Bioscience 61:183-193. doi:10.1525/bio.2011.61.3.4

Manson, S. M. 2001. Simplifying complexity: a review of complexity theory. Geoforum 32:405-414. doi:10.1016/ S0016-7185(00)00035-X

Martins, A. P., I. Anghinoni, S. E. V. G. A. Costa, F. S. Carlos, G. H. Nichel, R. A. P. Silva, and P. C. F. Carvalho. 2014a. Amelioration of soil acidity and soybean yield after surface lime reapplication to a long-term no-till integrated crop-livestock system under varying grazing intensities. Soil Tillage Res. 144:141-149. doi:10.1016/j. still.2014.07.019

Martins, A. P., S. E. V. G. A. Costa, I. Anghinoni, T. R. Kunrath, F. Balerini, D. Cecagno, and P. C. F. Carvalho. 2014b. Soil acidification and basic cation use efficiency in an integrated no-till crop-livestock system under different grazing intensities. Agric. Ecosyst. Environ. 195:18-28. doi:10.1016/j.agee.2014.05.012

Martins, A. P., T. R. Kunrath, I. Anghinoni, and P. C. F. Carvalho. 2015. Integração soja-bovinos de corte no sul do Brasil. UFRGS, Porto Alegre, Rio Grande do Sul, Brasil.

Maughan, M. W., J. P. C. Flores, I. Anghinoni, G. Bollero, F. G. Fernández, and B. F. Tracy. 2009. Soil quality and corn yield under crop-livestock integration in Illinois. Agron. J. 101:1503-1510. doi:10.2134/agronj2009.0068

McKenzie, S. C., H. B. Goosey, K. M. O’Neill, and F. D. Menalled. 2017. Integration of sheep grazing for cover crop termination into market gardens: agronomic consequences of an ecologically based management strategy. Renew. Agric. Food Syst. 32:389-402. doi:10.1017/S1742170516000326

Mirsky, S. B., M. R. Ryan, W. S. Curran, J. R. Teasdale, J. Maul, J. T. Spargo, J. Moyer, A. M. Grantham, D. Weber, T. R. Way, et al. 2012. Conservation tillage issues: cover crop-based organic rotational no-till grain production in the mid-Atlantic region, USA. Renew. Agric. Food Syst. 27:31-40. doi:10.1017/S1742170511000457

Moojen, F. G. 2017. A long-term study in an integrated crop-livestock system: exploring plant-animal relations in the pasture phase. MS Diss. Universidade Federal do Rio Grande do Sul, Porto Alegre.

Moraes, A., P. C. F. Carvalho, I. Anghinoni, S. B. C. Lustosa, S. E. V. G. A. Costa, and T. R. Kunrath. 2014. Integrated crop-livestock systems in the Brazilian subtropics. Eur. J. Agron. 57:4-9. doi:10.1016/j.eja.2013.10.004

Nichols, E., S. Spector, J. Louzada, T. Larsen, S. Amezquita, and M. E. Favila. 2008. Ecological functions and ecosystem services provided by Scarabaeinae dung beetles. Biol. Conserv. 141:1461-1474. doi:10.1016/j.biocon.2008.04.011 
Odum, E. P. 1953. Fundamentals of ecology. W. B. Saunders Company, Philadelphia, PA. doi: 10.1002/sce.3730380426

Oenema, O., C. Klein, and M. Alfaro. 2014. Intensification of grassland and forage use: driving forces and constraints. Crop Pasture Sci. 65:524-537. doi:10.1071/CP14001

Oliveira, C. A. O., C. Bremm, I. Anghinoni, A. Moraes, T. R. Kunrath, and P. C. F. Carvalho. 2013. Comparison of an integrated crop-livestock system with soybean only: economic and production responses in southern Brazil. Renew. Agric. Food Syst. 29:230-238. doi:10.1017/S1742170513000410

Oliveira, T. E., D. S. Freitas, M. Gianezini, C. F. Ruviaro, D. Zago, T. Z. Mércio, E. A. Dias, V. N. Lampert, and J. O. J. Barcellos. 2017. Agricultural land use change in the Brazilian Pampa biome: the reduction of natural grasslands. Land use policy. 63:394 400. doi:10.1016/j. landusepol.2017.02.010

Pitesky, M. E., Stackhouse, K. R., and F. M. Mitloehner. 2009. Clearing the air: livestock's contribution to climate change. In: D. Sparks, editor, Advances in agronomy. Academic Press, Inc., Burlington, MA. p. 1-40. doi:10.1016/ S0065-2113(09)03001-6

Rakkar, M. K., Blanco-Canqui, H., Drijber, R. A., Drewnoski, M. E., MacDonald, J. C., and T. Klopfenstein. 2017. Impacts of cattle grazing of corn residues on soil properties after 16 years. Soil Sci. Soc. Am. J. 81:414-424. doi:10.2136/sssaj2016.07.0227

Rocha, M. G., D. B. Montagner, D. T. dos Santos, F. K. Freitas, A. Pilau, and A. Frizzo. 2004. Parâmetros produtivos de uma pastagem temperada submetida a alternativas de utilização. Rev. Bras. Zootec. 33:1386-1395. doi:10.1590/ S1516-35982004000600005

Russelle, M. P., M. H. Entz, and A. J. Franzluebbers. 2007. Reconsidering integrated crop-livestock systems in North America. Agron. J. 99:325-334. doi:10.2134/ agronj2006.0139

Ryschawy, J., N. Choisis, J. P. Choisis, A. Joannon, and A. Gibon. 2012. Mixed crop-livestock systems: an economic and environmental-friendly way of farming? Animal 6:1722-1730. doi:10.1017/S1751731112000675

Sá, J. C., R. Lal, C. C. Cerri, K. Lorenz, M. Hungria, and P. C. de Faccio Carvalho. 2017. Low-carbon agriculture in South America to mitigate global climate change and advance food security. Environ. Int. 98:102-112. doi:10.1016/j.envint.2016.10.020

Salton, J. C., F. M. Mercante, M. Tomazi, and J. A. Zanatta. 2014. Integrated crop-livestock system in tropical Brazil: toward a sustainable production system. Agric. Ecosyst. Environ. 190:70-79. doi:10.1016/j.agee.2013.09.023

Sanderson, M. A., D. Archer, J. Hendrickson, S. Kronberg, M. Liebig, K. Nichols, M. Schmer, D. Tanaka, and J. Aguilar. 2013. Diversification and ecosystem services for conservation agriculture: outcomes from pastures and integrated crop-livestock systems. Renew. Agric. Food Syst. 28:129-144. doi:10.1017/S1742170512000312

Savian, J. V., A. B. Neto, D. B. David, C. Bremm, R. M. T. Schons, T. C. M. Genro, G. A. Amaral, J. Gere, C. M. McManus, C. Bayer, et al. 2014. Grazing intensity and stocking methods on animal production and methane emission by grazing sheep: implications for integrated crop-livestock system. Agric. Ecosyst. Environ. 190:112119. doi:10.1016/j.agee.2014.02.008

Schomberg, H. H., Fisher, D. S., Reeves, D. W., Endale, D. M., Raper, R. L., Jayaratne, K. S. U., Gamble, G. R., and M. B. Jenkins. 2014. Grazing winter rye cover crop in a cotton no-till system: yield and economics. Agron. J. 3:1041-1050. doi:10.2134/agronj12.0434

Shang, Z., Q. Gao, and M. Dong. 2003. Impacts of grazing on the alkalinized - salinized meadow steppe ecosystem in the Songnen Plain, China - a simulation study. Plant Soil 249:237-251.

Silva, F. D., T. J. C. Amado, C. Bredemeier, C. Bremm, I. Anghinoni, and P. C. F. Carvalho. 2014a. Pasture grazing intensity and presence or absence of cattle dung input and its relationships to soybean nutrition and yield in integrated crop-livestock systems under no-till. Eur. J. Agron. 57:84-91. doi:10.1016/j.eja.2013.10.009

Silva, F. D., T. J. C. Amado, A. O. Ferreira, J. M. Assmann, I. Anghinoni, and P. C. F. Carvalho. 2014b. Soil carbon indices as affected by 10 years of integrated crop-livestock production with different pasture grazing intensities in Southern Brazil. Agric. Ecosyst. Environ. 190:60-69. doi:10.1016/j.agee.2013.12.005

Silva, A. S., A. Colozzi Filho, A. S. Nakatani, S. J. Alves, D. S. Andrade, and M. F. Guimarães. 2015. Microbial characteristics of soils under an integrated crop-livestock system. Rev. Bras. Ciência do Solo 39:40-48. doi:10.1590/01000683rbcs20150185

Smukler, S. M., S. M. Philpott, L. E. Jackson, A. Klein, F. Declerck, L. Winowiecki, and C. A. Palm. 2012. Ecosystem services in agricultural landscapes. In: J. C. Ingram, F. DeClerck, and C. Rumbaitis del Rio, editors, Integrating ecology and poverty reduction: ecological dimensions. Springer New York, New York, NY. p. 17-51.

Soussana, J.-F., and G. Lemaire. 2014. Coupling carbon and nitrogen cycles for environmentally sustainable intensification of grasslands and crop-livestock systems. Agric. Ecosyst. Environ. 190:9-17. doi:10.1016/j.agee.2013.10.012

Souza, E. D., S. E. V. G. A. Costa, I. Anghinoni, M. A. C. Carneiro, A. P. Martins, and C. Bayer. 2014. Soil quality indicators in a Rhodic Paleudult under long term tillage systems. Soil Tillage Res. 139:28-36. doi:10.1016/j. still.2014.02.001

Souza, E. D. de, S. E. V. G. A. Costa, I. Anghinoni, C. V. S. Lima, P. C. F. Carvalho, and A. P. Martins. 2010. Soil microbial biomass in a no-tillage integrated crop-livestock system under different grazing intensities. Rev. Bras. Cienc. do Solo 34:79-88.

Souza, E. D., S. E. V. G. A. Costa, P. C. F. Carvalho, M. Adrigueti, and E. Cao. 2009. Soil organic carbon and nitrogen stocks in an untilled crop-livestock integration system under different grazing intensities. Rev. Bras. Cienc. do Solo 33:1829-1836.

Sulc, R. M., and A. J. Franzluebbers. 2014. Exploring integrated crop-livestock systems in different ecoregions of the United States. Eur. J. Agron. 57. doi:10.1016/j.eja.2013.10.007

Thornton, P. K., and M. Herrero. 2010. Potential for reduced methane and carbon dioxide emissions from livestock and pasture management in the tropics. Proc. Natl. Acad. Sci. U.S.A. 107:19667-19672. doi:10.1073/pnas.0912890107

Tilman, D., C. Balzer, J. Hill, and B. L. Befort. 2011. Global food demand and the sustainable intensification of agriculture. Proc. Natl. Acad. Sci. U.S.A. 108:20260-20264. doi:10.1073/ pnas. 1116437108

Tilman, D., J. Fargione, B. Wolff, C. D'Antonio, A. Dobson, R. Howarth, D. Schindler, W. H. Schlesinger, D. Simberloff, and D. Swackhamer. 2001. Forecasting agriculturally driven global environmental change. Science 292:281-284. doi:10.1126/science. 1057544 
Tracy, B. F., and Y. Zhang. 2008. Soil compaction, corn yield response, and soil nutrient pool dynamics within an integrated crop-livestock system in Illinois. Crop Sci. 48:12111218. doi:10.2135/cropsci2007.07.0390

Verhoeven, J. T., B. Arheimer, C. Yin, and M. M. Hefting. 2006. Regional and global concerns over wetlands and water quality. Trends Ecol. Evol. 21:96-103. doi:10.1016/j. tree.2005.11.015

Vermeulen, S. J., B. M. Campbell, and J. S. I. Ingram. 2012. Climate change and food systems. Annu.
Rev. Environ. Resour. 37:195-222. doi:10.1146/ annurev-environ-020411-130608

Vezzani, F. M., and J. Mielniczuk. 2009. Uma visão sobre qualidade do solo. Rev. Bras. Cienc. do Solo 33:743-755. doi:10.1590/S0100-06832009000400001

Xu, Z., G. Zhou, G. Han, and Y. Li. 2011. Photosynthetic potential and its association with lipid peroxidation in response to high temperature at different leaf ages in maize. J. Plant Growth Regul. 30:41-50. doi:10.1007/ s00344-010-9167-7 